Kodifikasia : Jurnal Penelitian Islam, Vol 15, No. 01 (2021), 89-110

DOI : 10.21154/kodifikasia.v15i1.2458

ISSN : 1907-6371 (Cetak)

ISSN : 2527-9254 (Online)

\title{
CONSUMER BEHAVIOR FOR LKMS-BMT MASLAHAH SIDOGIRI IN PASURUAN: INTERPRETATIVE STRUCTURAL MODELING APPROACH ANALYSIS STUDY
}

\author{
Parmujianto*
}

\begin{abstract}
ABSTRAK:
Perilaku Konsumen Lembaga Keuangan Mikro Sharia (LKMS)memiliki keunikan tersendiri terkait keputusan pemanfaatan produk jika dikaikan dengan lembaga keuangan sharia dan konvensional. BMT Maslahah (BMTM) Sidogiri Pasuruan merupakan salah satu Lembaga Keuangan Mikro Sharia (LKMS) yang menyediakan jasa keuangan yang berbasis sharia yang tidak lepas dari persepsi dan penilaian calon konsumen yang menggunakan produknya. Mesti secara kuantitatif telah terjadi peningkatan jumlah konsumen, BMT Maslahah belum melakukan identifikasi khusus terkait perilaku audience yang berpotensi menjadi tantangan di masa depan. penelitian ini menggunakan pendekatan kualitatif, yaitu análisis deskriptif dan Interpretative Structural Modeling (ISM). Hasil penelitian menunjukkan bahwa perilaku konsumen BMT Maslahah positif dalam penggunaan produk BMT Maslahah. Pemahaman dan sikap positif terhadap produk BMT Maslahah dilandasi oleh motif kebutuhan sehari-hari dan pengembangan usaha, disamping penerimaan nilai-nilai shariah berupa keberkahan dan keadilan ekonomi saat menggunakan produk BMT Maslahah. Upaya BMT Maslahah Sidogiri Pasuruan dalam membangun perilaku konsumtif kepada konsumen BMT Maslahah dengan mendekatkan pelayanan kepada masyarakat, meningkatkan rasio pengawas dan disiplin pengawasan serta mengembangkan beberapa produk sesuai dengan kebutuhan masyarakat, serta penguatan Sumber Daya Manusia (SDM)
\end{abstract}

Kata Kunci: Perilaku Konsumen; BMT-LKMS; Interpretative Structural Modeling.

* SekolahTinggi Agama IslamAl-YasiniPasuruan,Indonesia,email:parmujianto.008@ gmail.com 


\section{ABSTRACT:}

Consumer behavior The Sharia Micro Institution Institution (LKMS) has unique characteristics related to product utilization decision making when it is associated with Islamic and conventional financial institutions. BMT Maslahah (BMTM) Sidogiri Pasuruan is one of the LKMS that provides Sharia-based financial services that cannot be separated from the perceptions and assessments of potential consumers using their products. Even though quantitatively there has been an increase in the number of consumers, BMTM has not made specific identifications related to the behavior of the target audience which could potentially be a challenge in the future. This study uses a qualitative approach, namely descriptive analysis and Interpretative Structural Modeling (ISM). The results showed that consumer behavior in BMTM is positive in the utilization of BMTM products. Understanding and positive attitude towards BMTM products is based on the motives of daily necessities and business development, besides the factors of acceptance of sharia values in the form of blessing and economic justice when using BMTM products. The efforts of BMT Maslahah Sidogiri Pasuruan in building consumer behavior to BMT by bringing services closer to the community, increasing the ratio of supervisors and discipline of supervision and developing several products according to community needs, as well as strengthening human resources.

Keywords: Consumer Behavior; BMT- LKMS; Interpretative Structural Modeling

\section{INTRODUCTION}

The rapid economic development in Indonesia, also followed by the community's growing awareness of the importance of financial transaction facilities that are not only based on aspects of transaction security, but also includes ideological values in transactions. This awareness requires the public to choose suitable financial services in carrying out decision-making and / or behavior in the process of managing funds, contract models, and consumption behavior of the community, either individuals or organizations. The behavior of the community in carrying out the management of funds or financial transactions is currently influenced by religious values that are believed to be a source of truth. In Islam, efforts to manage funds and financial transactions in sharia continue to be developed, one of which is 
the existence of Islamic Micro Finance Institutions (LKMS), especially Baitul maal wa Tamwil (BMT) that practices religious values with sharia principles. ${ }^{1}$ Economic activity is always associated with production, distribution and consumption activities. In understanding how one's efforts to meet their needs with the resources they have, it is necessary to study consumer behavior to study how consumers behave and what factors influence the behavior. ${ }^{2}$

Consumer behavior in the LKMS environment, especially for BMT customers is also complex and cannot be easily predicted. As with consumer behavior on goods, consumers of financial services also experience changes, because consumer behavior can be formed and changed. Behavior starts from the formation of attitudes, which are tendencies that are learned in behaving in a way that is pleasant or unpleasant to an object. Attitude has 3 components, namely cognitive (knowledge), affective (attitude) and conative (behavior) of consumers. Behavioral positions and attitudes can change according to the situation, behavior can precede or follow the formation of attitudes. ${ }^{3}$

Consumer behavior is also influenced by religion and beliefs of adherents. BMT customers as a religious community that bases their behavior in accordance with certain religious norms that are believed, can be greatly influenced by religion. Religion in this sense can be seen only limited to problems, beliefs, divinity and worship alone. Religiosity is manifested in various aspects of human life. Though religion has a significant influence on how consumers behave. To a certain degree from a certain dimension complex religion turns out to shape economic behavior, although its influence is not uniform among various Muslim societies.

The study of consumer behavior from various religious groups actually has important value to get a picture for LKMS industry players in increasing their market share. The establishment of LKMS in the community and pesantren, such as BMT Maslahah Sidogiri, shows that there has been acceptance of non-ribawi financial institutions.

BMT has a strategic role in spurring economic growth in Indonesia so as to realize an increasingly balanced economic structure. The other side of the phenomenon of BMT in Indonesia can deliver people's understanding of economic institutions in Islam. The study of Islamic economics before

${ }^{1}$ Lely Ana Ferawati Ekaningsih, Lembaga Keuangan Syariah Bank dan Non Bank. (Kopertais Wilayah IV Surabaya), 2016

2 Philip Kotler dan Keller, Kvin Lane, Manajemen Pemasaran Edisi 12 jilid 2 Terjemahan Benyamin Molan ( Jakarta: Indeks), 2008.

3 Schiffman, Leon G., Kanuk, Lazar. Consumer Behavior.(International Edition Prentice Hall), 2012. 
the emergence of BMT is still in a theoretical form that has not been implemented.

The establishment of BMT is actually an effort to implement sharia economy in stages and is an integrated endeavor to overcome the weaknesses of Muslims in the economic and welfare fields. The existence of BMT is expected to be able to realize a financial system that is competitive, efficient, and meets the precautionary principle. Besides that, its existence is expected to be able to support the real sector through real financing activities based on the results and real transactions in realizing justice and helping each other to achieve the economic prosperity of the people.

The success of financial institutions such as Bank Muamalat, triggered the growth of non-bank Sharia Microfinance Institutions (LKMS) such as Baitul Mal Wa-Tamwil (BMT), sharia capital markets, sharia mutual funds, sharia pawnshops, sharia insurance, sharia insurance institutions and economic institutions that run with sharia principles. The success and continuity of BMT is highly expected by Muslims to be able to realize their goals. Therefore, for BMT to survive and develop properly, it must have healthy characteristics in accordance with standards set by Bank Indonesia.

In Sidogiri Village, Krato Subdistrict, Pasuruan Regency, an LKMS named BMT Maslahah (BMTM) Sidogiri was established on July 17, 1997, which was originally called MMT Cooperative MMU (Maslahahh Mursalah lil Ummah). BMTM Sidogiri has proven its existence from year to year experiencing rapid development and progress both in the number of members, employees and number of service offices, as well as financial performance.

Data from the Indonesian Ministry of Cooperatives and SMEs shows that in 2017 the number of MSMEs reached 62,922,617 business units (99.99\%) and Large Enterprises (LE) of 5,460 business units (0.01\%). Overall MSMEs absorb around $97 \%$ of the national workforce, while Large Enterprises only absorb around 3\% of the total national workforce. ${ }^{4}$ Of these total MSMEs, around 8 percent have marketed their products through online platforms in 2017.5

BMT as one of the financial mediation institutions in the community must maintain customer confidence. Without trust from customers, BMT

${ }^{4}$ Haryanti, D. M., \& Hidayah, I. Potret UMKM Indonesia: Si Kecil yang Berperan Besar. Retrieved October 23, 2019, from https://www.ukmindonesia.id/baca-artikel 62 / July 24. 2018.

5 Ayuwuragil, K. Kemenkop UKM: 3,79 Juta UMKM Sudah Go Online. Retrieved October 30, 2019, from Ekonomi website: https://www.cnnindonesia.com/ ekonomi/20171115161037-78-255819/kemenkop-ukm-379-juta-umkm-sudah-go-online . November 15, 2017.

Kodifikasia: Jurnal Penelitian Islam, Volume, 15 No. 1 Tahun 2021 
will not be able to run its business activities properly. Therefore, it is important for this institution to hold the principle of trust so that it can be trusted by customers. Trust arises through a long process so that customer satisfaction and behavior emerge until both parties trust each other. If trust has arisen between BMT and customers, then efforts to foster cooperation will be easier. This condition will be beneficial for both parties. From the institution, it benefits from customer behavior which is very useful for the survival of the institution. As for customers, they will get the right products to satisfy their choices.

Therefore, the effort to develop BMT is not enough just to be based on legal aspects and legislation but also must be oriented to the market or the community as service users (customers). This will affect people's perceptions and attitudes towards BMT. An important step that must be taken by BMT managers is to increase socialization through effective mass media, so that public knowledge about BMT is not only limited to product sharing. It is hoped that BMT customers will have more knowledge in making decisions about various types of products issued by BMT. Customers will have wise information related to BMT products.

According to Schiffman and Kanuk consumer behavior is a process that is passed by a consumer in finding, buying, using, evaluating and acting on the consumption of goods or services, as well as ideas that are expected to meet the needs of that person (Schiffman \& Kanuk, 2012). The action is carried out through being directly involved in the process of obtaining, consuming, disposing of a product (goods or services).

The growth of BMTM Sidogiri's performance is quite high when compared to other Islamic financial products from conventional banks in the Pasuruan region. This difference raises a big question that there are variations in performance between BMT and conventional financial institutions, due to differences in customer behavior and the characteristics of service delivery agencies. Therefore, this study aims to understand how consumer behavior in BMT Maslahah Sidogiri Pasuruan and institutional efforts in building consumer behavior.

The data in this study are primary collected through interview techniques on 111 BMT Maslahah consumer informants and also 3 (three) BMT experts namely, Dr. Ali Hamdan, MEI, H. Syaifudin Zuhri, MEI and H. M. Taufik. While this research model uses a qualitative approach with descriptive analysis method used to understand deeply and describe the conditions of information needs of consumer behavior in Baitul Mal Wa Tamwil (BMT) Maslahah Sidogiri Pasuruan. In addition, this study also uses Interpretative Structural Modeling (ISM) to analyze the needs of 
the development chain at BMT Maslahah Sidogiri Pasuruan. The basis for decision making in ISM techniques is groups. Structural models are produced to capture complex problems of a system, through carefully designed patterns using graphics and sentences. Through ISM techniques, mental models that are not clearly transformed into a system model that looks (visible).

The reason for the research using the Interpretative Structural Modeling model is a model that is able to support qualitative research analysis by presenting a hierarchy of elements that are able to photograph complex problems of a Sharia Microfinance Institution (LKMS)-BMT system using graphical form.

The location of this research is the Islamic Microfinance Institution at Baitul Mal Watamwil (BMT) Maslahah (hereinafter abbreviated as IMfIBMTM) in Sidogiri Pasuruan, East Java, Indonesia. The informants of this study were selected based on theoretical sampling techniques. ${ }^{6}$ LKMSBMTM customers, leaders and employees are figures who are assumed to have complete information related to the theme of this study and are therefore selected as informants. Various background informants will give different views because of differences in status in LKMS-BMTM. Informants involved in this study were 111 consumers (29 alumni and 82 non-alumni) LKMS-BMTM.

Interviews with semi-structured interfaces are used as data collection techniques and this is considered an appropriate approach and is used in qualitative research). ${ }^{7}$ With this approach it is possible to obtain complex information, which mostly contains opinions, attitudes, and personal experiences. The interview guide was created to direct the focus of the interview, containing global questions about the reasons why consumers remain loyal to LKMS-BMTM and how IMfI-BMTM leaders strive to maintain customer behavior. Generally, interviews are conducted during 1-1.5-hour sessions and this is in accordance with the general practice of qualitative research using the interview method ${ }^{8}$. All interviews are recorded to help in the analysis process. The interviews were interpreted using a thematic framework, that is, the conversational data were analyzed for recurrent themes and the relationships between these themes, which

${ }^{6}$ Creswell, J. W. Qualitative inquiry 83 research design: Choosing among five approaches (2nd ed.). Retrieved from http://www.loc.gov/catdir/enhancements/fy0701/2006031956-d. html. 2007.

${ }^{7}$ Creswell, J. W. Research design: Qualitative, quantitative, and mixed methods approaches (3rd ed.). Retrieved from http://www.loc.gov/catdir/toc/ecip0810/2008006242.html. 2009.

${ }^{8}$ Seidman, I. Interviewing as Qualitative Research: A Guide for Researchers in Education and the Social Sciences (5th ed.). New York, NY: Teachers College Press. (23015121). 2019.

Kodifikasia: Jurnal Penelitian Islam, Volume, 15 No. 1 Tahun 2021 
are brought together into categories based on their similarities. ${ }^{9}$ For ethical reasons, in this article, all references to the names of participants were eliminated. Data relating to LKMS-BMTM was collected through document review techniques. ${ }^{10}$ Documents reviewed were printed and electronic and include agency reports, minutes of meetings, customer records, and institutions.

\section{RESULT AND DISCUSSION}

\section{Background site}

BMT Maslahah Cooperative (BMTM) located in Sidogiri Pasuran, East Java, Indonesia has been established for 20 years, operating under Law number 17 of 2012 concerning Indonesian Cooperatives. The main mission of the establishment of BMTM is to address the ribawi economic practices in the community and to provide welfare for its members. Originally the BMTM cooperative consisted of only 348 people consisting of teachers and leaders and administrators of the Miftahul Ulum Madrasah of the Sidogiri Islamic Boarding School. The capital used for the business was obtained from the members' savings amounting to IDR13,500,000.

The development of the number of members and assets of BMTM is very rapid. In 2013 BMTM consisted of 2,999 people with total assets of IDR271,569,523,981.31. In the following four years, 2017, BMTM had 5,065 members (up by 68.9\%) with assets of IDR538,431,261,944.51 (up 98.3\%). In addition, BMTM also has fixed assets in the form of land, buildings, vehicles and office inventory.

The main business of this cooperative stems from savings and loans for members, then reaches a variety of halal business fields. The variety or types of businesses and services run by BMTM are also growing. Savings businesses include general sharia savings, wadiah savings, aqiqah/qurban savings, hajj savings, pilgrimage/travel savings, walimah savings, educational/institutional savings, and term deposits. Financing and loans include mudarabah (profit sharing), musharakah (inclusion), murabahah (buying and selling), al qard al-hasan (virtue), rahn (pawn), ijarah (rent), and pilgrimage bailout. Included in services are PPOB (Payment Point Online Banking), transfer

${ }^{9}$ Ritchie, J., \& Lewis, J. Qualitative Research Practice: A Guide for Social Science Students and Researchers. Retrieved from http://www.loc.gov/catdir/toc/fy037/2002109391. html. 2003.

${ }^{10}$ Bretschneider, P. J., Cirilli, S., Jones, T., \& Lynch, S. (2017). Document Review as a Qualitative Research Data Collection Method for Teacher Research. doi: 10.4135/9781473957435.2017. 
of students, hajj arrangements, other management services, and ticketing. Other businesses are the management of zakat, infaq, and shadaqah.

Now BMTM has 96 Service Offices (94 Sub-Branch Offices and 2 Cash Offices). The total management (management and employees) reaches approximately 650 people. BMTM employees undergo professional training in their area of work with trainers from professional financial institutions.

BMT collects funds from members and prospective members or the community with a wa di'ah or mudharabah/qiradh or qard agreement. Whereas lending or financing uses one of five types of contracts, namely mudharabah/qiradh, musyarakah/syirkah, murabahah, bai' bitsaman ajil and qard hasan. BMTM applies mu'amalah sharia pattern, i.e. not using interest rewards, but using profit sharing rewards for mudharabah and musharakah or profit rewards for Murabahah and Bai' Bitsamanil Ajil. Qard Hasan is usually used for activities that are social (non-profit).

\section{BMT Consumer Behavior Maslahah Sidogiri}

The results of the interview found several aspects and dimensions related to BMTM consumers. BMTM consumers in the form of savings or loans generally last more than 5 years, some even up to 22 years.

First, product information and credibility of information provision. The informant expressed his confidence in information about BMTM products because the ones providing the information were alumni friends, coworkers, family and or relatives, and neighbors. These sources of information are felt to be stronger in encouraging consumers, both alumni and the general public, to use BMTM products. The role of Sidogiri pesantren leaders and teachers in influencing the use of BMTM seems to be less strong. In fact, $74 \%$ of BMTM consumers from non-alumni circles and $26 \%$ from alumni indicated that leaders and teachers did not require alumni to use BMTM products. The process of product recognition by credible sources contributes to consumers' understanding of the product as well as the organizing agency.

Second, the decision to use. Owning an understanding of information about the product $\mathrm{d}$ oes not always make consumers use the product. Informants provide specific reasons related to the use of BMTM products, which can be categorized into three dimensions, namely the dimensions of value, operation al technical dimensions, and dimensions of specific needs. The dimension of values is related to sharia principles applied by BMTM. The infor $m$ ant believes that the value of religion must be actualized in the form of the use of financial products and the selection of financial institutions that are based on sharia principles. Included in the dimensions of the value of efforts to contribute to the strength of alumni

Kodifikasia: Jurnal Penelitian Islam, Volume, 15 No. 1 Tahun 2021 
ties and strengthen brotherhood among alumni. The operational technical dimension is related to service products provided by BMTM, including no deductions for administration, ease of access, and distance of the house from BMTM. Consumers assume that BMTM is a service institution that provides enough convenience compared to other financial services. The dimensions of specific needs is related to meeting the needs of daily life and this is the main reason. The fulfillment of future life needs is responded by storing and obtaining profit sharing, increasing business capital, and other forms of special needs such as education and worship activities.

Third, consumer behavior. The informants stated several indicators related to behavio $r$, namely the implementation of the sharia system, inviting others, and high satisfaction. The majority of informants stressed that the sharia values practiced in BMTM made them reluctant to move to other conventional financial institutions. This fact is supported by several previous studies that Muslims pay close attention to aspects of sharia before deciding to buy an item or use a service. ${ }^{11}$ Even shopping orientation factors, such as quality awareness, impulsive shopping, and price awareness are strongly related to a person's diversity. ${ }^{12}$ In addition, the study found that one's religiosity is an important factor in shaping shopping behavior for Muslims. ${ }^{13}$ In Muslim countries such as Indonesia, doing business or selling goods and services with sharia characteristics is an advantage in itself because most consumers are also Muslim and care about sharia aspects. Owning the same ideology and values as the BMTM business makes consumers loyal in utilizing BMTM products.

The majority of informants also tried to invite friends, relatives, and families to use BMTM products. This indicates that consumers have benefited from and believed in BMTM products, so high that they want others to use them too. Literature study found 6 main factors that have a positive influence on customer behavior, namely customer satisfaction, service quality, trust, values, comfort, and technology. ${ }^{14}$ Consumer confidence in a product can influence it to always buy products that are trusted. In addition, when someone has high trust in a product, it is very

${ }^{11}$ Ashraf Ali, K. (2016). Impact of Religiosity on Buying Behavior of Financial Products: A Literature Review. International Journal of Finance and Banking Research, 2(1), 18. doi: 0.11648/j.ijfbr.20160201.14. . 2016.

${ }^{12}$ Mokhlis, S. The Effect of Religiosity on Shopping Orientation: An Exploratory Study in Malaysia. 9(1), 11.2006.

${ }^{13}$ Shah Alam, S., Mohd, R., \& Hisham, B. Is religiosity an important determinant on Muslim consumer behaviour in Malaysia? Journal of Islamic Marketing, 2(1), 83-96. doi: 10.1108/17590831111115268. 2011.

${ }^{14}$ Al-Maamari, Q. A., \& Abdulrab, M. Factors Affecting on Customer Behavior in Service Organizations. 2 (5), 25-31. 2017 
likely he will invite others to buy the item. Recommending an item to someone else indicates trust in that item. ${ }^{15}$

The majority of informants from consumers are satisfied with BMTM products and services, so they still want to use it and will not even think of moving to other products. Customer satisfaction is an important factor in making it loyal to goods or services. ${ }^{16}$ Even the consumers behavior to a brand does not guarantee they will repeat buying if they do not feel satisfied with goods that have been purchased previously. ${ }^{17}$ Consumer behavior is also shown by the length of use of BMTM products and services, for example up to 22 years.

BMT Maslahah Sidogiri Pasuruan's consumer behavior can be mapped into two, namely consumer behavior coming from Alumni and non-alumni. The establishment of BMT Maslahah Sidogiri is inseparable from the role of the alumni. Starting from the concern of Miftahul Ulum Madrasyah teachers who saw the reality of community behavior which tended to pay less attention to sharia principles in the field of muamalah that carried out economic practices that led to ribawi which was forbidden by religion. Therefore, Sidogiri Islamic Boarding School alumni have the initiative of establishing cooperatives and then developing BMT Maslahah Sidogiri.

Consumer Behavior origi nating from Sidogiri Islamic Boarding School Alumni is on understanding and positive attitudes towards BMT Maslahah products based on the motives of daily necessities and business development, besides the factors of acceptance of sharia values in the form of blessing when using BMT Maslahah products. BMT Maslahah product introduction is sourced from alumni friends, friends or work colle agues, family, and neighbors in addition to proactive introduction of activities from the institution. Further information to confirm the initial information at the time of product introduction, is done by direct confirmation by visiting the BMT Maslahah, which minimizes disruption or misperception of financial services.

In addition to alumni, BMT consumers Maslahah Sidogiri also come from outside the pesantren environment. Behavior of BMT Maslahah financial service users coming from non-alumni includes a proper understanding of

${ }^{15}$ Todd, A. Trust Measures and Indicators for Customers and Investors. Journal of Behavioral Science, 1-45. 2007.

${ }^{16}$ Chiguvi, D., \& Guruwo, P. T. Impact of Customer Satisfaction on Customer Behavior in the Banking Sector. International Journal of Scientific Engineering and Research (IJSER), 5(2), 9. 2015.

${ }^{17}$ Saif, T., Ahmed, M., Shareef, S., \& Khalid, R. Characteristics of Brand Behavior: A Study on Apparel Industry. Mediterranean Journal of Basic and Applied Sciences (MJBAS), 2(2), 28. 2018. 
the product, a positive attitude towards products originating from BMT Maslahah, and awareness of acting in the form of selecting and using BMT Maslahah products. Understanding and positive attitudes towards BMT Maslahah products are based on the motives of daily necessities and business development, in addition to the factors of acceptance of sharia values in the form of blessing, but the motive of faith is not the driving force for the use of BMT Maslahah sharia products.

Based on interviews with consumers can be known several characteristics of BMT Maslahah consumers. Some background characteristics can be known from gender, age, level of education, occupation, and participation in learn ing in Islamic boarding schools. Overall consumers of BMT Maslahah are Muslim. The heterogeneity of people's backgrounds makes understanding of their religion also diverse. Consumers of BMT Maslahah are mostly male, and a small proportion are female. Generally, people who have family. The age range of consumers is between 20 to 64 years. Most are in the productive age group, aged 35-49 years.

The leve 1 of education of BMT Maslahah consumers varies from elementary school graduates to tertiary institutions. Formal education is pursued both inside and outside the boarding school. The community groups of high school graduates and elementary school graduates are the largest group of consumers, while a small proportion are junior high and college graduates. From this higher education group consumers are educated both from Diploma I and Bachelor graduates.

The deve lopment of the BMT Maslahah has also influenced an increasingly diverse number of boarding schools or santri alumni outside. More and more community groups outside pesantren alumni are entrusting or utilizing BMT Maslahah services. Even the latest developments show that the majority of BMT Maslahah consumers are dominated by nonalumni groups. This condition shows the trust of the community outside the large Islamic boarding schools towards BMT Maslahah.

When vie wed from a work or professional background, consumers are also very diverse. Various backgrounds from formal and informal work are the backgrounds of consumers. The largest group of BMT Maslahah consumers are company or factory employees, entrepreneurial groups, and Teachers. What is interesting is that quite a large number are groups who do not work in this case are housewives. Other groups are from farmers, students, government employees (village officials), farm workers, factory workers, as well as groups that really do not work (unemployed). This condition shows that BMT Maslahah has been accepted by many parties from professional or occupational backgrounds. 
Element Structure Model and BMT Maslahah Development Strategy

Through ISM techniques, mental models that are not clearly transformed into a system model that looks (visible). In this case the structure of the elements in the development of the BMT Maslahah is modeled according to the needs needed in the development of the BMT Maslahah.

The development of BMT Maslahah can be indicated in the increasing number of consumers and the higher quality of service as a consequence of organizational health. Both provide both direct and indirect influence in influencing consumer behavior. Based on studies and discussions with experts who are BMT practitioners and academics it can be concluded that there are two important elements related to the development of BMT Maslahah. These two elements are elements in the form of decision-making factors on product use \& BMT behavior and elements that cause problems in the development of health/organizational performance of BMTs.

Based on the results of the study, and the findings of consumer interviews and directional discussions with experts obtained factors that are sub-elements of the two elements that can be described as follows:

Table 1. Elements and Sub-elements related to BMT Development

\begin{tabular}{|l|l|l|l|}
\hline $\begin{array}{l}\text { Elements in the form of decision- } \\
\text { making factors for product use and } \\
\text { BMT behavior }\end{array}$ & $\begin{array}{l}\text { Elements that cause problems in } \\
\text { developing the health/performance } \\
\text { of BMT organizations }\end{array}$ \\
\hline No. & Sub-element & No. & Sub-element \\
\hline 1 & Product Attractiveness Offered & 1 & $\begin{array}{l}\text { Quality of Service to External } \\
\text { Customers }\end{array}$ \\
\hline 2 & $\begin{array}{l}\text { Attractiveness Rewards/Benefits } \\
\text { Benefits Provided }\end{array}$ & 2 & $\begin{array}{l}\text { Competence and Capability of } \\
\text { Organizational HR }\end{array}$ \\
\hline 3 & Service Satisfaction & 3 & $\begin{array}{l}\text { Service Quality and Internal } \\
\text { Customers }\end{array}$ \\
\hline 4 & Awareness of Sharia Principles & 4 & $\begin{array}{l}\text { Financing Risk Management } \\
\text { Practices }\end{array}$ \\
\hline 5 & Influential Reference Leads & 5 & $\begin{array}{l}\text { Third Party Fund Management } \\
\text { Practices }\end{array}$ \\
\hline 6 & Advantages of Competitors & 6 & Leadership Quality \\
\hline 7 & Trust in HR & 7 & $\begin{array}{l}\text { Clarity of Vision and } \\
\text { Organizational Orientation }\end{array}$ \\
\hline 8 & $\begin{array}{l}\text { Transfer Costs to Other Financial } \\
\text { Institutions }\end{array}$ & 8 & $\begin{array}{l}\text { Clarity of Control Systems } \\
\text { and SOPs for Activities }\end{array}$ \\
\hline & & 9 & $\begin{array}{l}\text { Ability to Adapt and See } \\
\text { Opportunities }\end{array}$ \\
\hline
\end{tabular}




\section{Structural Models of Maslahah BMT Development Elements}

Decision making referred to as described previously are the factors that are sub-elements of the decision making process in the use of BMT Maslahah products by consumers. Based on a literature review and the results of interviews with informants can be described as previously stated that the elements of decision making are as shown in the following table:

Table 2. Sub-element Decision Making Product Use and Behavior

\section{Sub-element Code}

E1 Product Attractiveness Offered

E2 Attraction Attraction / Benefits Benefits Provided

E3 Satisfaction with Service

E4 Awareness of Sharia Principles

E5 Influential Character Reference

E6 Excellence from Competitors

E7 Trust in HR

E8 Transfer Costs at Other Financial Institutions

Furthermore, based on the assessment activities of the resource persons and experts related to the decision-making element, the results of the assessment are based on the context of influence and relations between sub-elements. Furthermore, the assessment results are arranged in the form of initial Structural Similarity Index (SSIM). The initial SSIM is structured based on the relationships and interrelationships of the factors which are sub-elements of consumer decision making.

Diagram 1. DP-D matrix decision on the use of Products

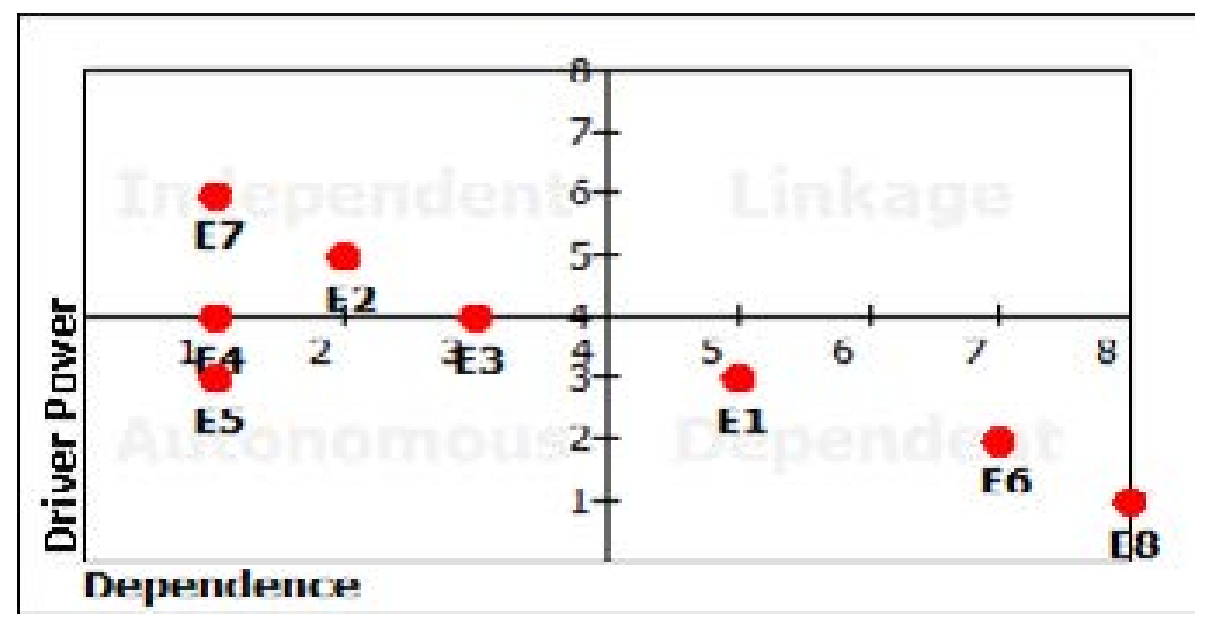

Based on the diagram, it can be explained that the whole trust subelement in BMT Maslahah HR holds the key that is able to move and 


\section{2 | Parmujianto}

influence other sub-elements, in this case the attractiveness of benefits and other sub-elements such as service satisfaction and awareness of the use of sharia products. This means that in the decision making process of using BMT Maslahah products, trust in HR is able to move and influence other sub-elements to make the decision making process using BMT Maslahah products.

In this case, the awareness of sharia principles is a sub-element group of middle categories in influencing and driving the decision making process of the use of BMT Maslahah products. As for the advantages of competitors and also the moving cost sub-element is a factor that has low mobility and dependability or dependence compared to other elements in influencing decision making on the use of Maslahah BMT products. Meanwhile, in terms of the Structural Dynamics of Development Problems, the dynamics of the problems referred to as described previously are aspects or factors that are sub-elements in the process of restructuring or BMT Maslahah performance. Based on a literature review and the results of interviews with informants can be described as previously stated and problems in the health of the BMT Maslahah organization can be shown in the following table:

Table 3. Dynamics Sub-elements of Organizational Health Problems

\begin{tabular}{|l|}
\hline Sub-element Code \\
\hline E1 Quality of Service to External Customers \\
\hline E2 Competencies and Capabilities of Organizational HR \\
\hline E3 Quality of Service and Internal Customers \\
\hline E4 Financing Risk Management Practices \\
\hline E5 Third Party Fund Management Practices \\
\hline E6 Quality of Leadership \\
\hline E7 Clarity of Vision and Organizational Orientation \\
\hline E8 Clarity of Control Systems and Activity SOPs \\
\hline E9 Ability to Adapt and See Opportunities \\
\hline
\end{tabular}

Furthermore, based on the assessment activities of the resource persons and experts related to the elements of health/organizational performance, the results of the assessment are based on the context of influence and relationships between sub-elements. Then the assessment results are arranged in the form of initial Structural Similarity Index (SSIM). The initial SSIM is structured based on the relationships and interrelationships of factors which are sub-elements of the health/performance of the organization. Furthermore, the initial SSIM which is a letter notation is converted to binary numbers so that it becomes a Reachability Matrix (RM). Then, considering the power of movement and its independence, 
the results of the revised RM matrix are then made into a structural model of the Dynamics of Organizational Health Problems in the form of a graph shown in the diagram as follows:

Diagram 2. DP-D matrix decision on the use of Products

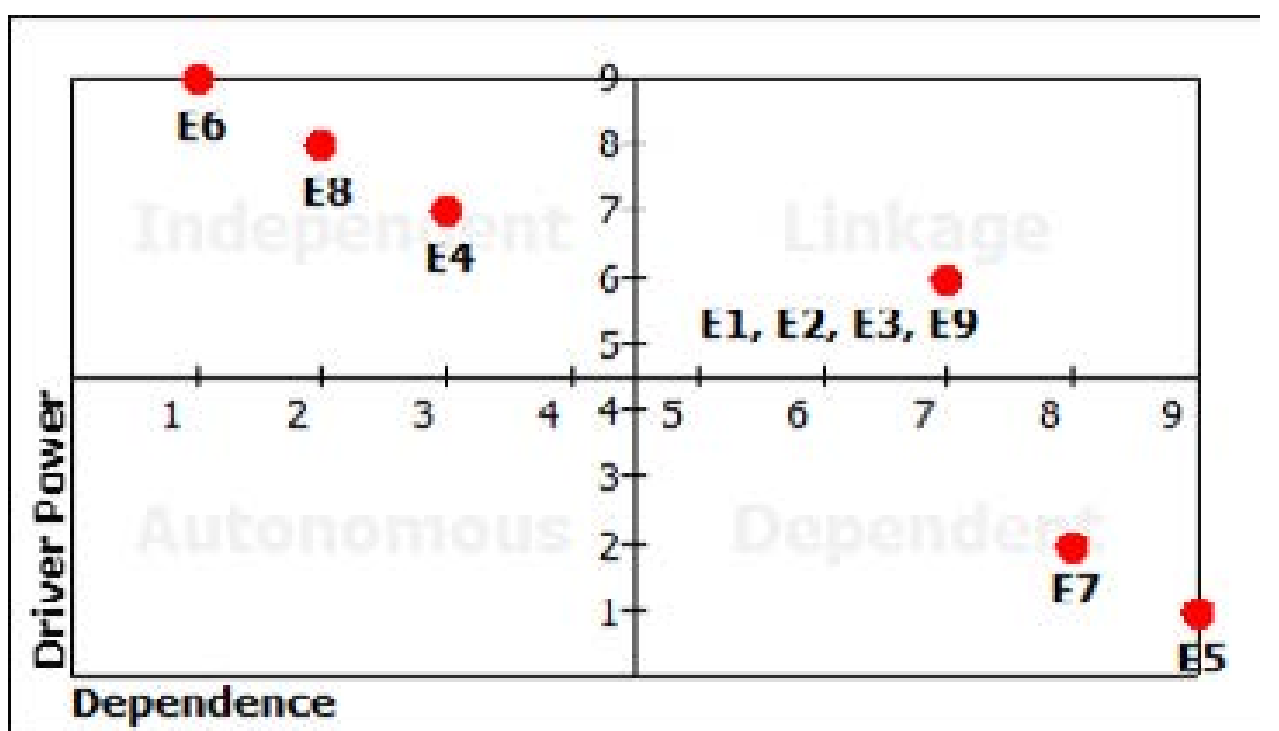

Based on these graphs it can be seen that the Quality of Leadership (E6) has the highest level of Control (Driver Power) and the Level of Freedom (Independence), while the Third Party Fund Management Practices (E5) are sub-elements which have the lowest Driver Power. This shows that E5 is a sub-element that is able to be influenced but cannot influence, and vice versa, E6 is a sub-element that is difficult to be influenced. In this case, E6 is a sub-element that has a very high influence in solving the problem of developing health/organizational performance of BMTs. From the results of modeling using Interpretative Structural Modeling (ISM) the diagram drawings are shown in the figure as follows: 
Chart 1. Structural Model of Dynamics of Organizational Health Problems

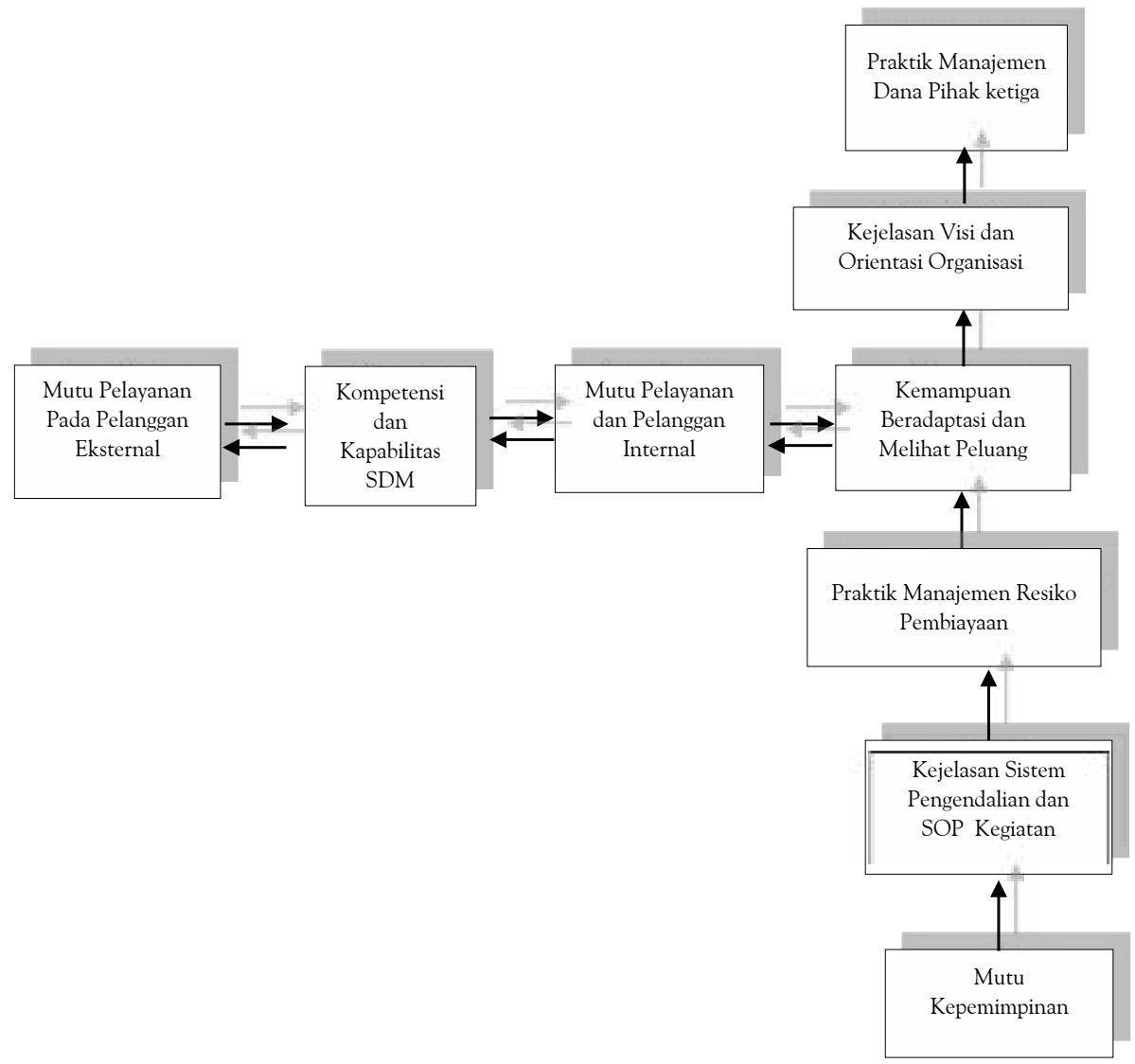

From the above structure it can be seen that the sub-element that has a very high ability in influencing the health problems of an organization is a reference to the quality of leadership, so to develop its business, BMT must have a strengthening of leadership quality carried out to the institution. Based on the chart it can be explained that the quality sub-elements of BMT Maslahah Leadership hold the key that is able to move and influence other sub-elements in this case Control of the SOP control System and Activities and other sub-elements such as Risk management practices. This means that in the process of solving problems to make the organization healthy, the BMT Maslahah leadership model must be able to move and influence other sub-elements.

In this case referring to Chart 1 , it can be explained that Adaptability, internal customer service quality, HR competencies and capabilities, and the quality of external customer service are sub-elements of the middle category in influencing and driving the organizational/organizational 
health/BMT Maslahah process. The clarity of the vision and also the subelements of management and third parties is a factor that has low mobility and dependability or dependence compared to other elements in influencing the process of solving the problem, especially the health and organizational performance of the BMT Maslahah.

Efforts to improve and develop BMT Maslahah as a microfinance institution that serves the community is a must. This necessity is caused by the fact that the number of BMT Maslahah roles actually contributes to the people's economy. Sharia principles are reflected in the form of acceptance by the public that BMT Maslahah has practices of justice, expediency, and convenience and is in favor of the small community continues to be fostered.

The development of the BMT Maslahah organization should be based on efforts to increase the number of consumers which is reflected in the increasing positive consumer behavior in the form of product behavior and efforts to improve organizational health and performance. Both of these are important factors in portraying the services of sharia-based financial institutions that are easily accessed by the community while providing the role of empowering the community. In addition, efforts to enhance organizational development must be truly based on the actual problems faced by BMT Maslahah while looking at the conditions of internal and external environmental challenges.

Based on the structuring of factors or sub-elements on how the decision making process in the use of BMT Maslahah products and the dynamics of probl e ms in organizational health and organizational performance, alternative scenarios and organizational development strategies for BMT Maslahah can be arranged. In strengthening the behavior of the use of products by consumers and in the context of developing the acceptance of BMT Maslahah products by potential consumers, the priority strategies that can be developed are:

First, increase trust in HR through strengthening the capacity and capabili t ies of BMT Maslahah HR. Strengthening the capacity and capability of BMT HR Maslahah can be done by improving the system of planning, recruitment, selection and placement of HR in a professional manner based on actual needs.

Second: increase the realization of the attractiveness of benefits/benefits provided by BMT Maslahah. The realization is in the form of careful and precise translation of service implementation based on the principles of shari'a a nd service satisfaction using a customer satisfaction oriented approach based on Integrated Quality Management (MMT). 


\section{6 | Parmujianto}

Third: st rengthen relationships with influential community figures who become community references and differentiation clearly strengthens the attractiveness of the products offered. BMT Maslahah socialization and silaturrahim as one of the media for facilitation and empowerment of Muslims must be carried out continuously for pesantren leaders and other reference groups.

While ef $f$ orts to solve the problem of strengthening the health/ performance of BMTM organizations, the strategies that can be developed are:

First: improve leadership quality at all levels of management and organizational structure of the BMT Maslahah. Strengthening leadership quality translates into capabilities and competencies for achieving a clear vision, leadership that involves and empowers members of the organization, sensitivity to environmental dynamics that challenges the development of the BMT Maslahah, and capabilities and competencies in carrying out organizational management.

Second: strengthen the Implementation of Control Systems and SOPs for activities and practices of financing risk management. As an organization providing financial services, strengthening implementation must be focused on efforts to clarify the BMT Maslahah business process and translate it in the form of standardization of all processes and activities in the form of SOP especially those related to the core BMT Maslahah business.

Third: increasing the ability to adapt and see opportunities, quality of service to internal and external customers, and structuring of professionalism of human resources. The improvement of service quality must be oriented towards external customers, as well as members of the organization, in this case all organizational HR as external customers. Satisfaction will give a positive meaning to the health of the organization because it becomes a motive driving performance.

Strategy development as stated earlier can be interpreted in the perspective of the priority of time or capability of resources owned by the BMT Maslahah institution. In this context if there are limited resources, the priorities submitted as a strategy for developing the BMT Maslahah are based on time. For example the first priority is the strategy that will be implemented in the first year and evaluates at the end of the year to recommend activities in the second year simultaneously or simultaneously with the implementation of the second priority strategy.

In addition, these priorities must be elaborated and coordinated both in strengthening the decision-making elements of product use and health/ organizational performance. Synergy must be carried out to facilitate the 
mobilization of limited resources to the Maslahah BMT organization to maximize the development strategy chosen as a priority. Synergy must also be managed in a management that is simple, measurable, planned, can be realized, and based on a clear timeline of performance. The commitment of all parties or stakeholders of BMT Maslahah is a big lever for the successful implementation of the strategy.

\section{CONCLUSIONS}

Consumer behavior in BMT Maslahah Pasuruan includes a proper understanding of the product, a positive attitude to the product, and awareness of acting in the form of selecting and using BMTM products. Understanding and positive attitude towards BMTM products is based on the motives of daily necessities and business development, besides the factors of acceptance of sharia values in the form of blessings when using BMTM products. Decision making is done after evaluation of further information search with the biggest use is savings or savings, loans or both savings and savings forms while behavior is formed after use due to positive confirmation in the form of satisfaction with the realization of the services offered.

BMT's efforts in building consumer behavior to BMT Maslahah Sidogiri Pasuruan by bringing services closer to the community include increasing trust in BMT HR, increasing the realization of the attraction of rewards, and strengthening relationships with influential figures in the community. Whereas to improve organizational performance the things that can be done are Improving the Quality of Leadership, Strengthening the Implementation of Control Systems and SOPs for activities and practices of financing risk management, and increasing the ability to adapt and see opportunities. 


\section{REFERENCE}

Al-Maamari, Q. A., \& Abdulrab, M. Factors Affecting on Customer Behavior in Service Organizations. 2(5), 25-31. 2017

Ali, Hasan. Perilaku Konsumen. Edisi Revisi. Jakarta: Refika Aditama, 2002.

Ashraf Ali, K. (2016). Impact of Religiosity on Buying Behavior of Financial

Products: A Literature Review. International Journal of Finance and Banking Research, 2(1), 18. doi: 0.11648/j.jifbr.20160201.14. . 2016.

Ayuwuragil, K. Kemenkop UKM: 3,79 Juta UMKM Sudah Go Online. Retrieved October 30, 2019, from Ekonomi website: https://www. cnnindonesia.com/ekonomi/20171115161037-78-255819/kemenkopukm-379-juta-umkm-sudah-go-online . 2017, November 15

Astuti, R., Marimin, Poerwanto R., Machfud, Askerman Y. Kebutuhan Dan Struktur Kelembagaan Rantai Pasok Buah Manggis Studi Kasus Rantai. 2010.

Assael, H. Consumer Behavior and Marketing Action. 4th Edition. Boston PWS Kent. 1992.

Bretschneider, P. J., Cirilli, S., Jones, T., \& Lynch, S. (2017). Document Review as a Qualitative Research Data Collection Method for Teacher Research. doi: 10.4135/9781473957435.2017.

Chiguvi, D., \& Guruwo, P. T. Impact of Customer Satisfaction on Customer Behavior in the Banking Sector. International Journal of Scientific Engineering and Research (IJSER), 5(2), 9. 2015.

Creswell, J. W. Qualitative inquiry $\mathcal{B}$ research design: Choosing among five approaches (2nd ed.). Retrieved from http://www.loc.gov/catdir/ enhancements/fy0701/2006031956-d.html. 2007.

Creswell, J. W. Research design: Qualitative, quantitative, and mixed methods approaches (3rd ed.). Retrieved from http://www.loc.gov/catdir/toc/ ecip0810/2008006242.html. 2009.

Danang Sunyoto, Perilaku Konsumen (Panduan Riset Sederhana untuk Mengenal Konsumen) Jakarta: CAPS. 2013.

David L. Laouden and Albert J. Della, Consumer Behavior: Concept an Aplication, The United States of America By Mc Graw Hill. Inc. 1984. 
Ekaninsih, LAF. Lembaga Keuangan Bank dan Non-Bank, Kopertais wilyah IV Surabaya. 2016.

Erna, Ferrinadewi. Merek dan Psikologi Konsumen, Implikasi pada Strategi Pemasaran, Graha Ilmu: Yogyakarta, 2008.

Hafidhuddin, Didin. Manajemen Syariah dalam Praktik. Jakarta:Gema Insani Press. 2003.

Haryanti, D. M., \& Hidayah, I. Potret UMKM Indonesia: Si Kecil yang Berperan Besar. Retrieved October 23, 2019, from https://www. ukmindonesia.id/baca-artikel/2018, July 24. 62

Ismail Nawawi Uha, Ekonomi Manajerial teori dan Aplikasi Dalam Bisnis (Sidoarjo dwiputra Pustaka Jaya,2014), 163-165

John, Mowen \& Monor, Monor. Perilaku Konsumen. Jakarta: Penerbit Erlangga. 2002.

Jones, Kevin Lance. Introduction to Consumer Behavior. New York: New York University. 2008.

Leon G. Schiffman dan Leslie Lazar Kanuk, Perilaku Konsumen terjemahan Zoelkifli Kasip, (Jakarata: Indeks, 2008).6

Loudon, D., dan Della Bitta, I.A,. Consumer Behavior: Concepts and Application, McGraw Hill. 1993.

Lewis, Mervyi \& Algaound, Latifa. Perbankan Syariah, Praktek, Prospek. Yogyakarta: Serambi. 2001.

Mokhlis, S. The Effect of Religiosity on Shopping Orientation: An Exploratory Study in Malaysia. 9(1), 11. 2006.

Muhammad Ahmad al-Assal dan Fathi Ahmad Abdul Karim, Sistem dan Prinsip, dan Tujuan Ekonomi Islam, Terjemahan Imam Saefudin. Bandung: Pustaka Setia. 1999.

Peter dan Olson, Perilaku dan Strategi Pemasaran. D. Sihombing (penterjemah). Consumen Behavior, Jakarta:Gelora Pratama, 1996.

Kotler, Philip. Building Customer Behavior Trough Quality, Upper Saddle River: Person Education. 2012.

Kotler, Philip dan Keller, Kvin Lane, Manajemen Pemasaran Edisi 12 jilid 2 Terjemahan Benyamin Molan ( Jakarta: Indeks, 2008), 214. 


\section{0 | Parmujianto}

Ritchie, J., \& Lewis, J. Qualitative Research Practice: A Guide for Social Science Students and Researchers. Retrieved from http://www.loc.gov/catdir/toc/ fy037/2002109391.html. 2003.

Robbin, Stephen P. Organizational Behavior, International Edition Prentice Hall, Inc. New Jersey: New York. 1998.

Saif, T., Ahmed, M., Shareef, S., \& Khalid, R. Characteristics of Brand Behavior: A Study on Apparel Industry. Mediterranean Journal of Basic and Applied Sciences (MJBAS), 2(2), 28. 2018.

Suxena JP. et. al. Herarchy and Classification of Program Plan Element Using Interpretative Structural Modelling. System Practice. Vol 12. 1992.

Schiffman, Leon G., Kanuk, Lazar. Consumer Behavior. International Edition Prentice Hall, 2012.

Setiadi, Nugroho. Perilaku Konsumen (Perspektif Kontemporer pada Motif, Tujuan dan Keinginan Konsumen. Jakarta: Kencana Prenada Media Group. 2015.

Seidman, I. Interviewing as Qualitative Research: A Guide for Researchers in Education and the Social Sciences (5th ed.). New York, NY: Teachers College Press. (23015121). 2019.

Shah Alam, S., Mohd, R., \& Hisham, B. Is religiosity an important determinant on Muslim consumer behaviour in Malaysia? Journal of Islamic Marketing, 2(1), 83-96. doi: 10.1108/17590831111115268. 2011.

Suhaenah, A, Suparno " Membangun Kopetensi Belajar" Direktorat Pendidikan Tinggi Departemen Pendidikan Nasional, 2001.

Todd, A. Trust Measures and Indicators for Customers and Investors. Journal of Behavioral Science, 1-45. 2007. 